УДК 581.135.51:582.998.2

\title{
КОМПОНЕНТНЫЙ СОСТАВ ЭФИРНОГО МАСЛА THYMUS BAICALENSIS SERG. (СЕMЕЙСТВО LAMIACEAE), ПРОИЗРАСТАЮЩЕГО НА ТЕРРИТОРИИ ВОСТОЧНОЙ СИБИРИ И МОНГОЛИИ
}

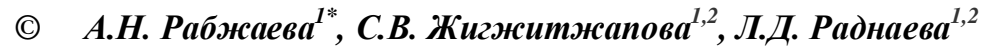 \\ ${ }^{1}$ Бурятский государственный университет, ул. Смолина, 24а, Улан-Удэ, \\ 670000 (Россия), e-mail: aryuna-In@mail.ru \\ 2Байкальский институт природопользования Сибирского отделения \\ Российской академии наук, ул. Сахьяновой, 6, Улан-Удэ, 670047 (Россия)
}

Исследован химический состав эфирного масла тимьяна байкальского (Thymus baicalensis Serg., Lamiaceae), произрастающего на территории России (Забайкальский край, Республика Бурятия, Иркутская область) и Монголии. Сбор материала проводили в местах естественного произрастания. Эфирное масло выделено методом гидродистилляции из надземной части растений. Компонентный состав масла исследован методом хромато-масс-спектрометрии. Идентифицировано 75 соединений. Общими для всех образцов являются борнеол, терпинеол-4, $\alpha$-терпинеол, карвакрол, гермакрен D, оксид кариофиллена. Доминирующими компонентами являются борнеол (до 18,51\%), терпинеол-4 (до 19,90\%), $\alpha$-терпинеол (до 52,51\%), карвакрол (до 57,30\%), а также в некоторых образцах - тимол (до 19,43\%). По составу эфирного масла тимьян байкальский близок к тимьяну ползучему и относится к хемотипу карвакрола. Карвакрол обнаружен во всех образцах, его содержание составляет от 0,1\% (Кабанский район Республики Бурятия) до 57,3\% (Хубсугульский аймак Монголии). Наибольшее количество тимола обнаружено в образце из Окинского района Республики Бурятия $(19,41 \%)$. Помимо карвакрола и тимола в эфирных маслах идентифицированы и их производные метиловые эфиры и ацетаты. Выявлена взаимосвязь между содержанием в масле монотерпенов ( $\alpha$-терпинеол, борнеол) и ароматических соединений ( $n$-цимол, тимол, карвакрол). Сесквитерпены в эфирных маслах тимьяна байкальского представлены в основном моно- и бициклическими соединениями. Содержание моноциклических сесквитерпенов варьирует от 0,70\% (Хубсугульский аймак Монголии) до 8,65\% (Тарбагатайский район Республики Бурятия); бициклических сесквитерпенов - от 1,38\% (Иволгинский район Республики Бурятия) до 16,00\% (Хоринский район Республики Бурятия).

Ключевые слова: эфирное масло, Thymus baicalensis Serg., Lamiaceae, хромато-масс-спектрометрия, Республика Бурятия, Забайкальский край, Иркутская область, Монголия.

Работа выполнена в рамках научно-исследовательской работы проектной части государственного задания в сфере научной деятельности (Задание № 19.1168.2014/К) и программы фундаментальных научных исследований государственных академий наук (проект V.46.5.2).

\section{Введение}

Род тимьян популярен в традиционной и официальной медицине многих стран как ценное лекарственное сырье. В России официнальными видами являются тимьян обыкновенный (Thymus vulgaris L.) и тимьян ползучий (Th. serpyllium L.) и применяются для лечения заболеваний органов дыхания [1]. Их

Рабжаева Арюна Николаевна - старший научный сотрудник, кандидат биологических наук, тел. (3012) 448-255, e-mail: aryuna-ln@ mail.ru Жигжитжапова Светлана Васильевна - старший научный сотрудник, кандидат биологических наук, доцент, e-mail: zhig@ binm.bscnet.ru, zhig2@yandex.ru Раднаева Лариса Доржиевна - заведующая лабораторией, доктор химических наук; профессор, e-mail: 1rad@ binm.bscnet.ru, radld@ mail.ru терапевтическое действие обусловлено эфирными маслами, которые обладают противовоспалительным, антибактериальным, фунгицидным, спазмолитическим и мочегонным действиями [2].

Флора Сибири насчитывает 35 видов растений рода Thymus (семейство Lamiaceae), в том числе в Забайкальском крае произрастает 9, в Иркутской области - 10 [3], в Республке Бурятия - 10 [4]

\footnotetext{
* Автор, с которым следует вести переписку.
} 
и в Монголии - 8 [5]. Одним из наиболее распространенных видов Восточной Сибири и Монголии является Thymus baicalensis Serg, [6].

Состав эфирного масла Thymus baicalensis Serg. практически не изучен, имеются сведения по составу эфирного масла растений флоры Монголии и Республики Бурятия. Для эфирного масла тимьяна байкальского, произрастающего на территории Монголии, характерно большое содержание тимола, $n$-цимола при небольших количествах карвакрола [7]. В то время как эфирное масло Thymus baicalensis Serg. из Бурятии характеризуется высоким содержанием карвакрола, $n$-цимола, $\gamma$-терпинена, борнеола [8].

В настоящей работе мы приводим результаты изучения состава эфирного масла Thymus baicalensis Serg., произрастающего на территории России (Республика Бурятия, Забайкальский край, Иркутская область) и Монголия.

\section{Экспериментальная часть}

Сбор растительного материала был проведен на территории Бурятии, Иркутской области, Забайкальского края и Монголии в период 2008-2014 гг. (табл. 1). Thymus baicalensis распространен в сообществах степного типа растительности, относящихся к подтипам настоящих, луговых и горных степей. С экотопологической точки зрения Thymus baicalensis предпочитает каменистые экотопы склонов гор и подгорных шлейфов, степные и лесостепные ландшафты, произрастает в основном на щебнисто-каменистых, каштановых почвах, лугово-аллювиальных черноземах. Гербарные образцы хранятся в лаборатории химии природных систем БИП СО РАН и ФГБОУ ВПО «БГУ».

Эфирное масло получали из воздушно-сухой массы надземных частей растений методом гидродистилляции. Сырье сушили в сухом, хорошо проветриваемом прохладном месте в течение недели, затем выделяли эфирное масло. Содержание эфирного масла определяли в 50 г измельченного сырья методом 2 согласно ГФ ХІ (вып. 1), время перегонки - 3 ч. Состав эфирного масла сразу после выделения исследовали методом хроматомасс-спектрометрии на газовом хроматографе Agilent 6890 с квадрупольным масс-спектрометром (MSD 5973N) в качестве детектора сразу после его выделения. Для разделения была использована 30-метровая кварцевая колонка HP-5MS с внутренним диаметром 0,25 нм. Газ-носитель - гелий (чистота 99,999\%). Условия хроматографирования: изотермический режим при $50{ }^{\circ} \mathrm{C}$ в течение 5 мин, затем программируемый подъем температуры со скоростью $4{ }^{\circ} \mathrm{C} /$ мин до $280{ }^{\circ} \mathrm{C}$ с выдержкой при конечной температуре 20 мин.

Таблица 1. Характеристика исследованных образцов Thymus baicalensis Serg

\begin{tabular}{|c|c|c|c|}
\hline $\begin{array}{l}\text { № } \\
\text { П/ח }\end{array}$ & Место сбора, год сбора & $\begin{array}{c}\text { Высота над } \\
\text { уровнем моря, м }\end{array}$ & $\begin{array}{l}\text { Выход масла }(\%) \\
\text { от массы в.с.с. }\end{array}$ \\
\hline 1 & Россия, Забайкальский край, вблизи р. Энда, 2014 & 700 & 0,23 \\
\hline 2 & $\begin{array}{l}\text { Россия, Республика Бурятия, Хоринский район, окрестности с. Хоринск, } \\
2014\end{array}$ & 540 & 0,20 \\
\hline 3 & $\begin{array}{l}\text { Россия, Республика Бурятия, Тарбагатайский район, окрестности с. Тар- } \\
\text { багатай, } 2014\end{array}$ & 690 & 0,10 \\
\hline 4 & $\begin{array}{l}\text { Россия, Республика Бурятия, Кабанский район, окрестности с. Шергино, } \\
\text { дата сбора, } 2014\end{array}$ & 750 & 0,05 \\
\hline 5 & $\begin{array}{l}\text { Россия, Республика Бурятия, Иволгинский район, окрестности пос. } \\
\text { Сотниково, } 2008\end{array}$ & 548 & 1,30 \\
\hline 6 & $\begin{array}{l}\text { Россия, Республика Бурятия, Бичурский район, окрестности с. Средний } \\
\text { Харлун, } 2008\end{array}$ & 757 & 1,01 \\
\hline 7 & $\begin{array}{l}\text { Россия, Республика Бурятия, Кяхтинский район, окрестности г. Кяхта, } \\
2008\end{array}$ & 732 & 0,80 \\
\hline 8 & Россия, Иркутская область, о. Ольхон, 2008 & 579 & 0,21 \\
\hline 9 & Россия, Иркутская область, Приморский хребет, 2008 & 463 & 1,22 \\
\hline 10 & $\begin{array}{l}\text { Россия, Республика Бурятия, Селенгинский район, окрестности } \\
\text { с. Селенгинск, } 2008\end{array}$ & 688 & 0,80 \\
\hline 11 & $\begin{array}{l}\text { Россия, Республика Бурятия, Окинский район, местность Цинцин талай, } \\
2008\end{array}$ & 1346 & 1,20 \\
\hline 12 & $\begin{array}{l}\text { Россия, Республика Бурятия, Закаменский район, окрестности с. Баянгол, } \\
2008\end{array}$ & 700 & 1,03 \\
\hline 13 & $\begin{array}{l}\text { Россия, Республика Бурятия, Заиграевский район, окрестности } \\
\text { пос. Заиграево, } 2008\end{array}$ & 550 & 0,70 \\
\hline 14 & Монголия, Хубсугульский район, 2008 & 1645 & 1,00 \\
\hline
\end{tabular}


Температура испарителя составляет $280{ }^{\circ} \mathrm{C}$, температура интерфейса между хроматографом и массдетектором $-280{ }^{\circ} \mathrm{C}$, температура источника ионов и квадруполя $-250{ }^{\circ} \mathrm{C}, 150{ }^{\circ} \mathrm{C}$ соответственно, энергия ионизирующих электронов - 70 эВ. Деление потока - 60 : 1. Процентный состав компонентов эфирного масла был вычислен по площадям хроматографических пиков без использования корректирующих коэффициентов. Качественный анализ основывался на сравнении рассчитанных значений линейных индексов удерживания, времен удерживания, полных масс-спектров с библиотекой хромато-массспектрометрических данных летучих веществ растительного происхождения. Вычисление линейных индексов удерживания $J$ выполняли в соответствии с [9]. Количественный анализ осуществляли методом внутренней нормировки по площадям пиков без использования корректирующих коэффициентов.

\section{Обсуждение результатов}

Выход эфирного масла из надземной части Thymus baicalensis Serg. составил 0,05-1,30\% в пересчете на воздушно-сухое сырье (табл. 1). Эфирное масло представляет собой легкоподвижную жидкость желтого цвета с приятным специфическим запахом. В составе эфирных масел идентифицировано 75 соединений (табл. 2).

Эфирные масла Thymus baicalensis Serg., как и масла других тимьянов, характеризуются высоким содержанием ароматических соединений, биогенетически связанных с монотерпенами [10, 11]. Общими соединениями для всех образцов являются борнеол, терпинеол-4, $\alpha$-терпинеол, карвакрол, гермакрен $\mathrm{D}$, оксид кариофиллена. Доминирующими компонентами являются борнеол (до 18,51\%), терпинеол-4 (до $19,90 \%$ ), $\alpha$-терпинеол (до 52,51\%), карвакрол (до 57,30\%), а также в некоторых образцах - тимол (до $19,43 \%)$. Выявлена взаимосвязь между содержанием в масле монотерпенов ( $\alpha$-терпинеол, борнеол) и ароматических соединений ( $n$-цимол, тимол, карвакрол). Уменьшение количества в эфирном масле одного из перечисленных веществ приводит к увеличению содержания других, что указывает на биогенетическую взаимосвязь между ними (рис.).

Изученные нами образцы эфирного масла Thymus baicalensis Serg. относятся к фенольному хемотипу и характеризуется высоким содержанием карвакрола, чем тимола, при наличии $n$-цимола, $\gamma$-терпинена и кариофиллена. Карвакрол обнаружен во всех образцах, его содержание составляет от 0,1\% (Кабанский район Республики Бурятия) до 57,3\% (Хубсугульский аймак Монголии). Наибольшее количество тимола обнаружено в образце из Окинского района Республики Бурятия $(19,41 \%)$. Помимо карвакрола и тимола в эфирных маслах идентифицированы и их производные - метиловые эфиры и ацетаты. Различное количество тимола, карвакрола в наших образцах можно объяснить влиянием экологических условий произрастания растений на их содержание [11]. Известно, что указанный хемотип масла характерен для тимьянов, произрастающих в северных широтах [12], и растения фенольного хемотипа лучше защищены от микроорганизмов [13], так как и тимол, и карвакрол обладают выраженными антисептическими и фунгицидными свойствами [14]. Интересно, что наименьшее количество $(0,91 \%)$ ароматических соединений обнаружено в эфирном масле из растений, произрастающих на минимальной (550м, Заиграевский район Республики Бурятия), а максимальное количество (77,74\%) на максимальной для наших сборов высоте над уровнем моря (1645 м, Хубсугульский аймак Монголии). Однако прямой закономерности между содержанием ароматических соединений в эфирном масле и высотой над уровнем моря места произрастания тимьяна байкальского не прослеживается.

Только в образце эфирного масла тимьяна байкальского из Закаменского района Республики Бурятия в качестве основного компонента обнаружен ациклический монотерпеновый спирт - гераниол $(4,20 \%)$ и его производные - гераниаль $(0,42 \%)$ и геранилацетат $(4,01 \%)$. Известна лимонная форма тимьяна ползучего (Thymus serpyllum L. s. L., f. citriodora), масло которого содержит до 60-70\% гераниола [11].

Сесквитерпены в эфирных маслах тимьяна байкальского представлены в основном моно- и бициклическими соединениями и их общее содержание составляет от 3,93 до 24,65\% (табл. 2). Содержание моноциклических сесквитерпенов варьирует от 0,70\% (Хубсугульский аймак Монголии) до 8,65\% (Тарбагатайский район Республики Бурятия); бициклических сесквитерпенов - от 1,38\% (Иволгинский район Республики Бурятия) до 16,00\% (Хоринский район Республики Бурятия). Наибольшее накопление бициклических сесквитерпенов (16,00 и 10,66\% соответственно) происходят в растениях, произрастающих в Хоринском (образец 2) и Кабанском (образец 4) районах Республики Бурятия. Увеличение в эфирном масле суммарного содержания и структурного разнообразия сесквитерпеновых соединений, в частности повышение содержания бициклических соединений, может быть обусловлено условиями территорий произрастания растений - аридным [15] и холодным [16] климатом. 
Таблица 2. Химический состав эфирного масла Thymus baicalensis Serg., произрастающих на территории Восточной Сибири и Монголии по данным хромато-масс-спектрометрии

\begin{tabular}{|c|c|c|c|c|c|c|c|c|c|c|c|c|c|c|c|}
\hline \multirow{3}{*}{ Компоненты } & \multicolumn{15}{|c|}{ Номера образцов по таблице 1} \\
\hline & $J$ & 1 & 2 & 3 & 4 & 5 & 6 & 7 & 8 & 9 & 10 & 11 & 12 & 13 & 14 \\
\hline & \multicolumn{15}{|c|}{ Содержание идентифицированных компонентов в \% от цельного масла } \\
\hline 1 & 2 & 3 & 4 & 5 & 6 & 7 & 8 & 9 & 10 & 11 & 12 & 13 & 14 & 15 & 16 \\
\hline \multicolumn{16}{|c|}{ Монотерпены } \\
\hline \multicolumn{16}{|c|}{ Ароматические соединения } \\
\hline$n$-цимол & 1039 & 0,76 & 3,61 & 14,69 & 10,85 & & 15,00 & 6,21 & 10,91 & 14,40 & 1,12 & 12,01 & 14,62 & 0,91 & 6,73 \\
\hline тимол & 1292 & & & & 9,84 & 1,02 & 0,62 & 0,92 & 5,82 & 5,02 & 0,51 & 19,43 & 3,30 & + & 6,10 \\
\hline карвакрол & 1302 & 0,16 & 20,28 & 22,71 & 27,12 & 21,41 & 36,40 & 39,29 & 3,41 & 29,80 & 41,10 & 30,20 & 14,40 & + & 57,30 \\
\hline метиловый эфир тимола & 1236 & & & & 1,07 & & & & & & & & 0,30 & & \\
\hline метиловый эфир карвакрола & 1375 & & & & & & & & & & & & 0,29 & & \\
\hline тимолацетат & 1356 & & & & 0,39 & & & & & 0,20 & & 1,41 & 0,10 & + & 1,40 \\
\hline карвакролацетат & 1375 & & & & 2,05 & 2,70 & 1,61 & 1,90 & & 1,60 & & & 0,80 & + & 6,21 \\
\hline куминовый альдегид & 1241 & & & & & & & & & & & & 0,10 & & \\
\hline эвгенол & 1359 & & & & 0,28 & & & & & 0,10 & & 2,58 & & & \\
\hline ионол & 1514 & & & & & & & & & & & & & & 0,50 \\
\hline $\begin{array}{l}\text { Сумма ароматических со- } \\
\text { единений }\end{array}$ & & 0,92 & 23,89 & 37,40 & 51,6 & 25,13 & 53,63 & 48,32 & 20,14 & 51,10 & 42,73 & 67,26 & 33,91 & 0,91 & 78,24 \\
\hline \multicolumn{16}{|c|}{ Ациклические монотерпены } \\
\hline$\beta$-мирцен & 991 & 11,58 & & 0,56 & 0,76 & 1,92 & 0,40 & 1,02 & 5,91 & 0,62 & 5,22 & 0,91 & 3,33 & 5,52 & 0,42 \\
\hline линалоол & 1100 & 0,56 & & 0,39 & 0,52 & 1,12 & 1,20 & 1,32 & 1,12 & 1,82 & 4,60 & 2,42 & 1,20 & 0,62 & 1,10 \\
\hline транс- $\beta$-оцимен & 1048 & + & & & & & & & & 0,12 & 0,11 & & & & \\
\hline гераниол & 1255 & & & & & & & & & 4,20 & & & & & \\
\hline гераниаль & 1273 & & & & & & & & & 0,42 & & & & & \\
\hline артемизия спирт & 1084 & & & & 0,25 & & & & & & & & & & \\
\hline геранилацетат & 1385 & & & & & & & & & 4,01 & & & & & \\
\hline периллен & 1101 & 0,51 & & & & & & & & & & & & & \\
\hline цитронеллол & 1229 & 0,43 & & & & & & & & & & & & & \\
\hline транс-карвеол & 1219 & 0,10 & & & & & & & & & & & & & \\
\hline цис-дигидрокарвон & 1198 & & & & & & & & & & & & 0,20 & & \\
\hline $\begin{array}{l}\text { Сумма ациклических } \\
\text { монотерпенов }\end{array}$ & & 13,18 & & 0,95 & 1,53 & 3,04 & 1,60 & 2,34 & 7,03 & 11,19 & 9,93 & 3,33 & 4,73 & 6,14 & 1,52 \\
\hline \multicolumn{16}{|c|}{ Моноциклические монотерпеньы } \\
\hline$\alpha$-терпинен & 1009 & 0,22 & & 1,18 & 1,56 & 0,92 & 1,20 & 0,91 & 0,70 & 1,82 & 0,61 & 1,13 & 1,62 & 0,70 & 0,41 \\
\hline лимонен & 1028 & 1,76 & & 0,47 & 0,38 & & 0,40 & 0,31 & 1,90 & 0,51 & 0,78 & 0,39 & 1,23 & 1,90 & \\
\hline
\end{tabular}


Продолжение таблицы 2

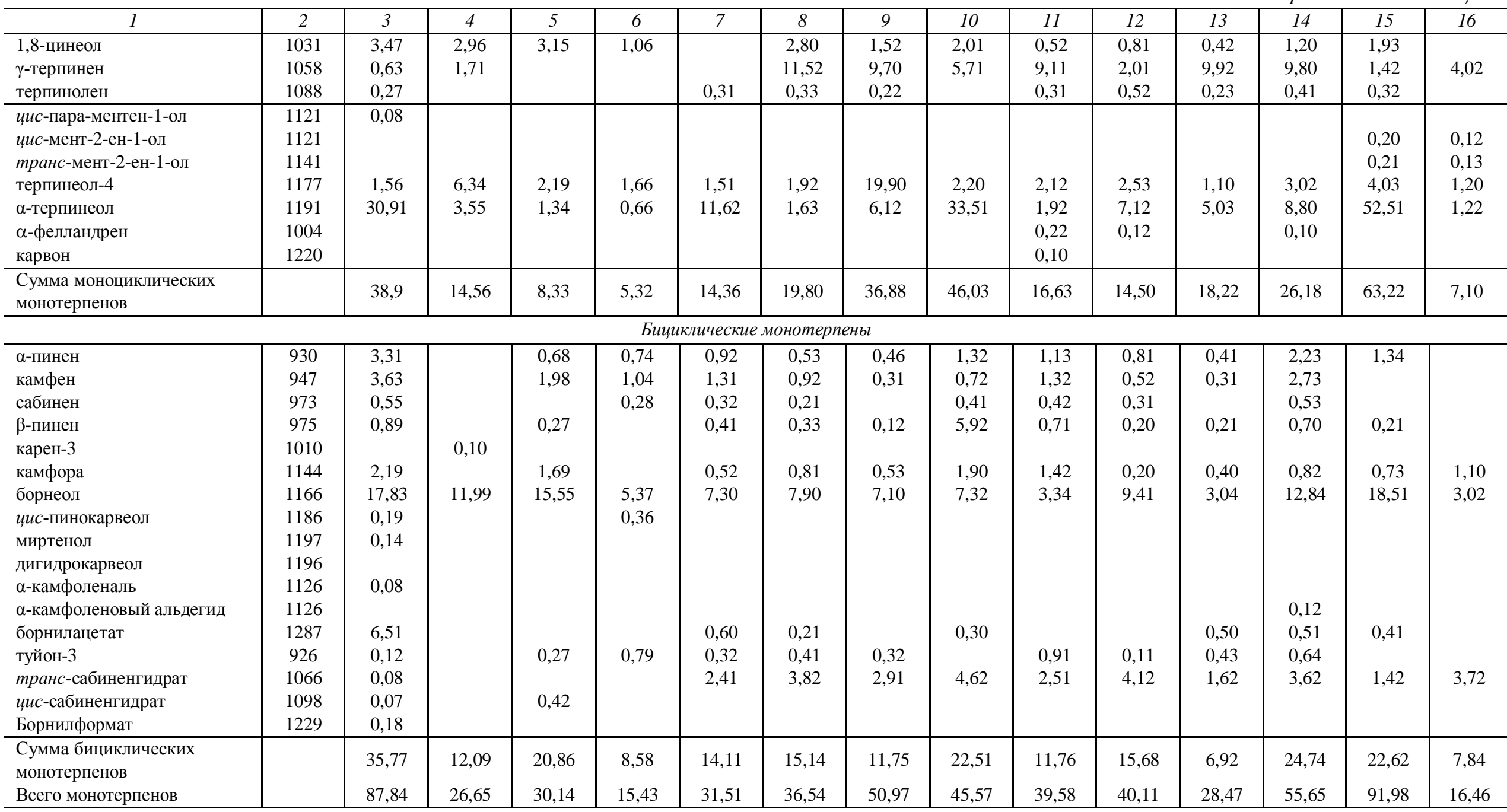

Сесквитерпены

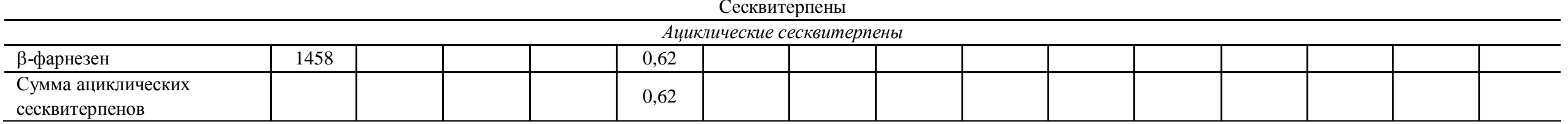




\begin{tabular}{|c|c|c|c|c|c|c|c|c|c|c|c|c|c|c|c|}
\hline 1 & 2 & 3 & 4 & 5 & 6 & 7 & 8 & 9 & 10 & 11 & 12 & 13 & 14 & 15 & 16 \\
\hline \multicolumn{16}{|c|}{ Моноииклические сесквитерпены } \\
\hline$\beta$-элемен & 1392 & 0,10 & & 0,66 & & & & & & + & & & & & \\
\hline гумулен & 1456 & 0,06 & & & & & & 0,21 & & 0,10 & & & 1,20 & & \\
\hline гермакрен D & 1484 & 1,31 & 8,65 & 6,36 & 3,44 & 1,01 & 0,90 & 1,90 & 3,01 & 1,20 & 1,30 & 0,90 & 0,70 & + & 0,60 \\
\hline$\beta$-бисаболен & 1511 & 0,09 & & 0,57 & & & & & & 0,10 & & & + & & \\
\hline$\alpha$-бисаболен & 1506 & 1,46 & & & & 0,70 & 2,01 & 2,69 & 0,50 & 1,59 & 1,40 & & & + & \\
\hline хризантенон & 1126 & & & & 0,34 & & & & & & & & & & 0,10 \\
\hline$\beta$-копаен & 1432 & 0,10 & & 0,66 & & & & & & + & & & & & \\
\hline $\begin{array}{l}\text { Сумма моноциклических } \\
\text { сесквитерпенов }\end{array}$ & & 3,12 & 8,65 & 2,25 & 3,78 & 1,71 & 2,91 & 4,80 & 3,51 & 2,99 & 2,70 & 0,90 & 1,90 & + & 0,70 \\
\hline \multicolumn{16}{|c|}{ Бициклические сесквитерпены } \\
\hline кариофиллен & 1422 & & & & & 3,10 & 2,50 & 3,88 & 2,30 & 1,70 & 2,00 & 2,30 & 0,10 & + & 2,90 \\
\hline оксид кариофиллена & 1596 & 0,72 & 4,17 & 0,45 & 1,07 & 2,20 & 1,50 & 1,29 & 1,30 & 1,01 & 0,40 & 1,02 & 0,59 & + & 1,51 \\
\hline эпи-9-кариофиллен & 1469 & & & 1,38 & 3,25 & & & & & & & & & & \\
\hline$\delta$-кадинен & 1527 & & & & & & & 0,39 & & 0,19 & & 0,20 & 0,69 & 1,20 & \\
\hline$\gamma$-кадинен & 1517 & 0,15 & & & & & & 0,20 & & 0,10 & & & & 1,19 & \\
\hline$\gamma$-муролен & 1480 & 0,10 & & & & & & 0,20 & & 0,10 & & & & & \\
\hline$\beta$-селинен & 1488 & & & & 5,07 & & & & & & & & & & \\
\hline бициклогермакрен & 1500 & 0,11 & 11,83 & 0,52 & 1,27 & 0,30 & 0,41 & 0,50 & & & 0,20 & & & & 1,01 \\
\hline$\alpha$-кадинол & 1658 & 0,10 & & & & & & & & & & & & & \\
\hline$\beta$-кубебен & 1392 & + & & & & & & & & & & & & & \\
\hline$\beta$-бурбонен & 1387 & 0,21 & & & & & & & & 0,10 & & & & 1,59 & \\
\hline эпи-9-изокариофиллен & 1463 & 1,01 & & & & & & & & & & & & & \\
\hline изокариофиллен-12-ацетокси & 1794 & 0,13 & & & & & & & & & & & & & \\
\hline$\delta$-аморфен & 1509 & 0,22 & & & & & & & & & & & & & \\
\hline $\begin{array}{l}\text { Сумма бициклических сескви- } \\
\text { терпенов }\end{array}$ & & 2,75 & 16,00 & 2,35 & 10,66 & 5,60 & 4,41 & 6,46 & 3,60 & 3,20 & 2,42 & 3,52 & 1,38 & 3,98 & 5,42 \\
\hline \multicolumn{16}{|c|}{ Трициклические сесквитерпены } \\
\hline $\begin{array}{l}\text { спатчуленол } \\
\text { трициклен }\end{array}$ & $\begin{array}{c}1580 \\
921\end{array}$ & 0,21 & & & $\begin{array}{c}1,02 \\
14,15\end{array}$ & & 0,39 & 0,21 & & 0,12 & & 0,20 & 0,11 & 0,29 & 0,60 \\
\hline $\begin{array}{l}\text { Сумма трициклических се- } \\
\text { сквитерпенов }\end{array}$ & & 0,21 & & & 15,17 & & 0,39 & 0,21 & & 0,12 & & 0,20 & 0,11 & 0,29 & 0,60 \\
\hline Всего сесквитерпенов & & 6,08 & 24,65 & 4,6 & 30,23 & 7,31 & 7,71 & 11,47 & 7,11 & 6,31 & 5,12 & 4,62 & 3,39 & 4,27 & 6,72 \\
\hline \multicolumn{16}{|c|}{ Алифатические соединения } \\
\hline циклогексанол & 885 & & & & 0,26 & & & & & & & & & & \\
\hline октен-1-3-ол & 979 & 0,46 & & 0,41 & 0,36 & 0,41 & 0,42 & 0,61 & 0,80 & 0,91 & 0,72 & 0,51 & 0,92 & 0,12 & \\
\hline октан-3-ол & 996 & 0,77 & & & & & & & & & & & & & \\
\hline $\begin{array}{l}\text { Сумма алифатических } \\
\text { соединений }\end{array}$ & & 1,23 & & 0,41 & 0,62 & 0,41 & 0,52 & 0,61 & 0,80 & 0,91 & 0,72 & 0,51 & 0,92 & 0,12 & \\
\hline
\end{tabular}

соединений

Примечание. * знак «+» означает, что содержание соответствующего компонента не превышает $0,1 \%$. 
Биогенетическая связь между основными компонентами эфирного масла Thymus baicalensis Serg (цифрами 1-14 обозначены номера образцов по таблице 1)

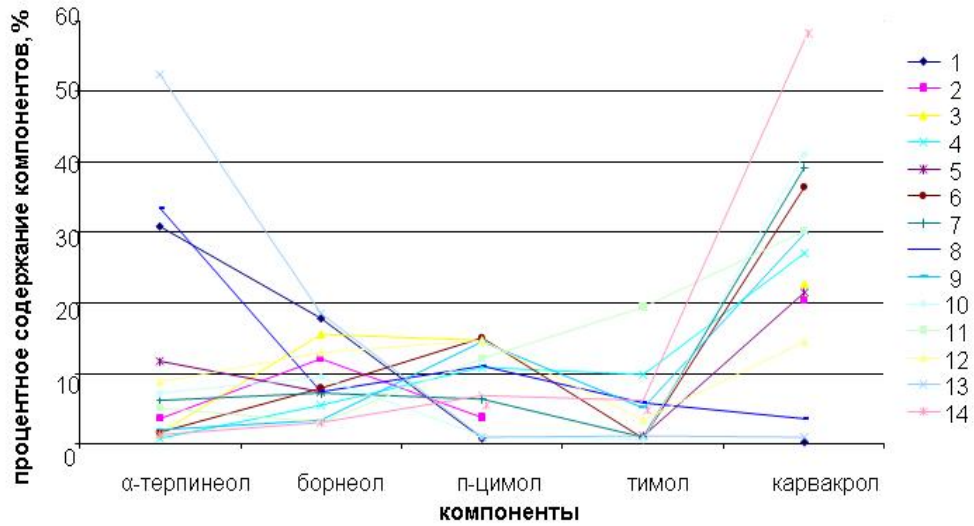

\section{Bbыводbl}

Таким образом, при исследовании состава эфирного масла Thymus baicalensis Serg., произрастающего в Восточной Сибири и Монголии, идентифицировано 75 соединений. Эфирное масло тимьяна байкальского по составу основных компонентов близко к эфирному маслу, типичному для Thymus serpyllum L. и относится к хемотипу карвакрола. Полученные результаты показывают перспективность дальнейшего использования эфирного масла Thymus baicalensis Serg. в качестве источника новых лекарственных средств и биологически активных добавок, обладающих антисептическими, противовоспалительными и противомикробными свойствами.

\section{Сиисок литературы}

1. Государственная фармакопея СССР: Вып. 2. Общие методы анализа. Лекарственное растительное сырье. М., 1990. $400 \mathrm{c}$.

2. Помазанов В.В., Марданлы С.Г., Борисов В.Ю. Экологическая лаборатория - Ваша домашняя аптечка растительных настоек, сиропов и масел. Владимир, 2012. 184 с.

3. Флора Сибири. Pyrolaceae - Lamiaceae (Labiatae). Новосибирск, 1997. T. 11. С. 205-211.

4. Аненхонов О.А. Определитель растений Бурятии. Улан-Удэ, 2001. 672 с.

5. Грубов В.И. Определитель сосудистых растений Монголии (с атласом) - Монголын цоргот ургамал таних бичиг (аурийн хамтаар). Л., 1982. С. 218.

6. Шатар С., Бодоев Н.В., Жигжитжапова С.В., Алтанцэцэг Ш., Намзалов Б.Б. Эфироносные растения бассейна реки Селенга. Улан-Удэ, 2006. С. 68.

7. Shatar S. Chemical investigation of essential oil from Mongolian flora. Ulaan-baatar, 1998. 166 p.

8. Жигжитжапова С.В., Рабжаева А.Н., Звонцов И.В., Раднаева Л.Д. Химический состав эфирного масла тимьяна байкальского Thymus baicalensis Serg., произрастающего в Забайкалье // Химия растительного сырья. 2008. №1. С. 73-76.

9. Ткачёв А.В. Исследование летучих веществ растений. Новосибирск, 2008. 969 с.

10. Eds Stahl_Biskup E., Saez F. Thyme: The Genus Thymus. London, New York: Taylor, Francis, 2002. 330 p.

11. Банаева Ю.А., Покровский Л.М., Ткачев А.В. Исследование химического состава эфирного масла представителей рода Thymus L., произрастающих на Алтае // Химия растительного сырья. 1999. №3. C. 41-48.

12. Войткевич С.А. Эфирные масла для парфюмерии и ароматерапии. М., 1999. 282 с.

13. Amiot J., Salmon Y., Collin C., Thompson J.D. Differential Resistance to Freezing and Spatial Distribution in a Chemically Polymorphic Plant Thymus vulgaris // Ecol. Lett. 2005. Vol. 8. Pp. 370-377.

14. Feo V.D., Bruno M., Tahiri B., Napolitano F., Senatore F. Chemical Composition and Antibacterial Activity of Essential Oils from Thymus spinulosus Ten. (Lamiaceae) // J. Agric. Food Chem. 2003. Vol. 51. Pp. 3849-3853.

15. Жигжитжапова С.В., Рандалова Т.Э., Раднаева Л.Д., Тараскин В.В., Чимитцыренова Л.И. Эфирные масла Artemisia vulgaris L., произрастающей на территории Республики Бурятия: состав и сравнение с литературными данными // Фундаментальные исследования. 2014. №8(1). С. 68-73.

16. Алексеева Л.И., Груздев И.В. Полиморфизм эфирного масла тимьянов европейского северо-востока России и Урала // Физиология растений. 2012. Т. 59. №6. С. 771-780.

Поступило в редакиџюю 23 января 2015 г. 
Rabzhaeva A.N. ${ }^{1}$, Zhigzhitzhapova S.V. ${ }^{1,2}$, Radnaeva L.D. ${ }^{1,2}$ COMPONENT COMPOSITION OF THE ESSENTIAL OILS OF THYMUS BAICALENSIS SERG. (LAMIACEAE), GROWNING IN THE EASTERN SIBERIA AND MONGOLIA

${ }^{I}$ Buryat State University, ul. Smolina, 24a, Ulan-Ude, 670000 (Russia), e-mail: aryuna-In@mail.ru

${ }^{2}$ Baikal institute of Nature Management, Siberian Branch, Russian Academy of Sciences, ul. Sakhyanovoy, 6, Ulan-Ude, 670047 (Russia)

Plants of genus Thymus (Lamiaceae) are very popular in traditional and officinal medicine of many countries. Thymus baicalensis Serg. is one of the most common species in Eastern Siberia and Mongolia. We investigated the chemical composition of the essential oil of Th. baicalensis which grows in Russia (Zabaikalsky region, Republic of Buryatia, Irkutsky region) and Mongolia. The essential oil was isolated by hydrodistillation from the aerial part of the plants. Composition of oil was analyzed by the gas chromatography-mass spectrometry. Borneol, terpinen-4-ol, $\alpha$-terpineol, carvacrol, thymol are the main components of Th. baicalensis from all points of sampling. Carvacrol content varied from $0,1 \%$ (Kabansky region of Republic of Buryatia) to 57,3\% (Khubsugul aimag of Mongolia). The greatest number of thymol was found in the sample from Oka district of Buryatia $(19,41 \%)$. Sesqiterpenese in the oil of Th. baicalensis were presented by mono- and bicyclic compounds. The content of monocyclic sesquiterpenes varied from $0,70 \%$ (Khubsugul aimag of Mongolia) to 8,65\% (Tarbagataisky district of Buryatia); bicyclic sesquiterpenes - from 1,38\% (Ivolginsky district of Buryatia) to 16,00\% (Khorinsky district of Buryatia). The components of essential oil of Th. baicalensis are determined by the genes, which it goes from, and the environmental factors. Determination of composition of essential oil is important to learn more about Thymus sp. around the whole world.

Keywords: essential oil, Thymus baicalensis Serg., chromatography-mass spectrometry, Zabaykalskiy kray, Republic of Buryatia, Irkutsk region.

\section{References}

1. Gosudarstvennaja farmakopeja SSSR: Vyp. 2. Obshhie metody analiza. Lekarstvennoe rastitel'noe syr'e. [The State pharmacopoeia of the USSR: vol. 2. General methods of analysis. Medicinal herbs]. Moscow, 1990, 400 p. (in Russ.).

2. Pomazanov V.V., Mardanly S.G., Borisov V.Ju. Jekologicheskaja laboratorija - Vasha domashnjaja aptechka rastitel'nyh nastoek, siropov $i$ masel. [Environmental Laboratory - Your home kit herbal tinctures, syrups and oils]. Vladimir, 2012, 184 p. (in Russ.).

3. Flora Sibiri. Pyrolaceae - Lamiaceae (Labiatae). [Flora of Siberia. Pyrolaceae - Lamiaceae (Labiatae)]. Novosibirsk, 1997, vol. 11, pp. 205-211. (in Russ.).

4. Anenhonov O.A. Opredelitel' rastenij Burjatii. [Guide to the Plants of Buryatia]. Ulan-Udje, 2001, 672 p. (in Russ.).

5. Grubov V.I. Opredelitel' sosudistyh rastenij Mongolii (s atlasom) - Mongolyn corgot urgamal tanih bichig (aurijn hamtaar). [The vascular plants of Mongolia (with the atlas) - Mongolyn tsorgot Urgamal tanih bichig (auriyn hamtaar)]. Leningrad, 1982, p. 218. (in Russ.).

6. Shatar S., Bodoev N.V., Zhigzhitzhapova S.V., Altancjecjeg Sh., Namzalov B.B. Jefironosnye rastenija bassejna reki Selenga. [Efironosnye plants Selenga River Basin]. Ulan-Udje, 2006, p. 68. (in Russ.).

7. Shatar S. Chemical investigation of essential oil from Mongolian flora. Ulaan-baatar, 1998. $166 \mathrm{p}$.

8. Zhigzhitzhapova S.V., Rabzhaeva A.N., Zvoncov I.V., Radnaeva L.D. Himija rastitel'nogo syr'ja, 2008, no. 1, pp. 73-76. (in Russ.).

9. Tkachjov A.V. Issledovanie letuchih veshhestv rastenij. [The study of plant volatiles]. Novosibirsk, 2008, 969 p. (in Russ.).

10. Eds Stahl_Biskup E., Saez F. Thyme: The Genus Thymus. London, New York: Taylor, Francis, 2002, 330 p.

11. Banaeva Ju.A., Pokrovskij L.M., Tkachev A.V. Himija rastitel'nogo syr'ja, 1999, no. 3, pp. 41-48. (in Russ.).

12. Vojtkevich S.A. Jefirnye masla dlja parfjumerii i aromaterapii. [Essential oils for perfumes and aromatherapy]. Moscow, 1999, 282 p. (in Russ.).

13. Amiot J., Salmon Y., Collin C., Thompson J.D. Ecol. Lett. 2005, vol. 8, pp. 370-377.

14. Feo V.D., Bruno M., Tahiri B., Napolitano F., Senatore F. J. Agric. Food Chem. 2003, vol. 51, pp. 3849-3853.

15. Zhigzhitzhapova S.V., Randalova T.Je., Radnaeva L.D., Taraskin V.V., Chimitcyrenova L.I. Fundamental'nye issledovanija. 2014, no. 8(1), pp. 68-73. (in Russ.).

16. Alekseeva L. I., Gruzdev I. V. Fiziologija rastenij. 2012, vol. 59, no. 6, pp. 771-780. (in Russ.).

Received January 23, 2015

Revised March 24, 2015

\footnotetext{
* Corresponding author.
} 